\title{
Basic science: (OCTOBER 2007)
}

1. Cao YX, Luo JL and Karin M. IкB kinase $\alpha$ kinase activity is required for self-renewal of ErbB2/Her2-transformed mammary tumorinitiating cells. Proc Natl Acad Sci USA 2007; 104: 15852-15857.

2. Charafe-Jauffret E, Monville F, Bertucci F, Esterni B, Ginestier C, Finetti P, Cervera N, Geneix J, Hassanein M, Rabayrol L, Sobol H, Taranger-Charpin C, Xerri L, Viens P, Birnbaum $\mathrm{D}$ and Jacquemier J. Moesin expression is a marker of basal breast carcinomas. Int $\mathrm{J}$ Cancer 2007; 121: 1779-1785.

3. Cheng JW, Yu DV, Zhou JH and Shapiro DJ. Tamoxifen induction of CCAAT enhancerbinding protein $\alpha$ is required for tamoxifeninduced apoptosis. J Biol Chem 2007; 282: 30535-30543.

4. Degen M, Brellier F, Kain R, Ruiz C, Terracciano L, Orend $G$ and Chiquet-Ehrismann R. Tenascin-W is a novel marker for activated tumor stroma in low-grade human breast cancer and influences cell behavior. Cancer Res 2007; 67: 9169-9179.

5. Durocher F, Labrie Y, Ouellette G and Simard J. Genetic sequence variations and ADPRT haplotype analysis in French Canadian families with high risk of breast cancer. J Hum Genet 2007; 52: 963-977.

6. Emlet DR, Brown KA, Kociban DL, Pollice AA, Smith CA, Ong BBL and Shackney SE. Response to trastuzumab, erlotinib, and bevacizumab, alone and in combination, is correlated with the level of human epidermal growth factor receptor-2 expression in human breast cancer cell lines. Mol Cancer Ther 2007; 6: 2664-2674.

7. Jakobsen CG, Rasmussen N, Laenkholm AV and Ditzel HJ. Phage display-derived human monoclonal antibodies isolated by binding to the surface of live primary breast cancer cells recognize GRP78. Cancer Res 2007; 67: 9507-9517.

8. John EM, Schwartz GG, Koo J, Wang W and Ingles SA. Sun Exposure, Vitamin D Receptor

$\mathrm{BCO} / 665 / 2007 / \mathrm{JW}$
Gene Polymorphisms, and Breast Cancer Risk in a Multiethnic Population. Am J Epidemiol 2007; 166: 1409-1419.

9. Karnoub AE, Dash AB, Vo AP, Sullivan A, Brooks MW, Bell GW, Richardson AL, Polyak $K$, Tubo $R$ and Weinberg RA. Mesenchymal stem cells within tumour stroma promote breast cancer metastasis. Nature 2007; 449: 557-563.

10. Khaleque MA, Bharti A, Gong J, Gray PJ, Sachdev V, Ciocca DR, Stati A, Fanelli M and Calderwood SK. Heat shock factor 1 represses estrogen-dependent transcription through association with MTA1. Oncogene 2007; 10.1038/sj.onc.1210834.

11. Kim SJ, Nakayama S, Miyoshi Y, Taguchi T, Tamaki Y, Matsushima T, Torikoshi Y, Tanaka S, Yoshida T, Ishihara $\mathrm{H}$ and Noguchi S. Determination of the specific activity of CDK1 and CDK2 as a novel prognostic indicator for early breast cancer. Ann Oncol 2007; 10.1093/ annonc/mdm358.

12. Kotzsch M, Sieuwerts A, Grosser M, Meye A, Fuessel S, Meijer-van Gelder M, Smid $M$, Schmitt M, Baretton G, Luther T, Magdolen V and Foekens J. Urokinase receptor splice variant uPAR-del4/5-associated gene expression in breast cancer: identification of rab31 as an independent prognostic factor. Breast Cancer Res Treat 2007; 10.1007/s10549-0079782-6.

13. Lauber SN and Gooderharn NJ. The cooked meat-derived genotoxic carcinogen 2-Amino3-Methylimidazo[4,5-b]Pyridine has potent hormone-like activity: Mechanistic support for a role in breast cancer. Cancer Res 2007; 67: 9597-9602.

14. Li Cl, Malone KE, Daling JR, Potter JD, Bernstein L, Marchbanks PA, Strom BL, Simon MS, Press MF, Ursin G, Burkman RT, Folger SG, Norman S, McDonald JA and Spirtas R. Timing of Menarche and First Full-Term Birth in Relation to Breast Cancer Risk. Am J Epidemiol 2007; 10.1093/aje/kwm271.

15. Lu DM, Sivaprasad U, Huang J, Shankar E, Morrow $S$ and Basu A. Protein kinase C-epsilon 
protects MCF-7 cells from TNF-mediated cell death by inhibiting Bax translocation. Apoptosis 2007; 12: 1893-1900.

16. Ma L, Teruya-Feldstein $\mathrm{J}$ and Weinberg RA. Tumour invasion and metastasis initiated by microRNA 10b in breast cancer. Nature 2007; 449: 682-688.

17. Menendez JA and Lupu R. Fatty acid synthase and the lipogenic phenotype in cancer pathogenesis. Nat Rev Cancer 2007; 7: 763-777.

18. Migliaccio A, Varricchio L, De Falco A, Castoria G, Arra C, Yamaguchi H, Ciociola A, Lombardi M, Di Stasio R, Barbieri A, Baldi A, Barone MV, Appella $E$ and Auricchio F. Inhibition of the $\mathrm{SH} 3$ domain-mediated binding of Src to the androgen receptor and its effect on tumor growth. Oncogene 2007; 26: 6619-6629.

19. Miller WR, Larionov AA, Renshaw L, Anderson TJ, White S, Murray J, Murray E, Hampton G, Walker JR, Ho S, Krause A, Evans DB and Dixon JM. Changes in breast cancer transcriptional profiles after treatment with the aromatase inhibitor, letrozole. Pharmacogenetics Genomics 2007; 17: 813-826.

20. Millikan R, Newman B, Tse C, Moorman P, Conway K, Dressler L, Smith L, Labbok M, Geradts J, Bensen J, Jackson S, Nyante S, Livasy C, Carey L, Earp $\mathrm{H}$ and Perou C. Epidemiology of basal-like breast cancer. Breast Cancer Res Treat 2007; 10.1007/ s10549-007-9790-6.

21. Pu J, McCaig CD, Cao L, Zhao ZQ, Segall JE and Zhao M. EGF receptor signalling is essential for electric-field-directed migration of breast cancer cells. J Cell Sci 2007; 120: 3395-3403.

22. Pujana MA, Han JDJ, Starita LM, Stevens KN, Tewari M, Ahn JS, Rennert G, Moreno V, Kirchhoff T, Gold B, Assmann V, ElShamy WM, Rual JF, Levine D, Rozek LS, Gelman RS, Gunsalus KC, Greenberg RA, Sobhian B, Bertin N, Venkatesan K, Ayivi-Guedehoussou N, Sole X, Hernandez P, Lazaro C, Nathanson KL, Weber BL, Cusick ME, Hill DE, Offit K, Livingston DM, Gruber SB, Parvin JD and Vidal M. Network modeling links breast cancer susceptibility and centrosome dysfunction. Nat Genet 2007; 39: 1338-1349.

23. Roberts CG, Gurisik E, Biden TJ, Sutherland RL and Butt AJ. Synergistic cytotoxicity between tamoxifen and the plant toxin persin in human breast cancer cells is dependent on Bim expression and mediated by modulation of ceramide metabolism. Mol Cancer Ther 2007; 6: 2777-2785.

24. Schmidt MK, Reincke S, Broeks A, Braaf LM, Hogervorst FBL, Tollenaar R, Johnson N, Fletcher O, Peto J, Tommiska J, Blomqvist C,
Nevanlinna HA, Healey CS, Dunning AM, Pharoah PDP, Easton DF, Doork T and Van't Veer LJ. Do MDM2 SNP309 and TP53 R72P interact in breast cancer susceptibility? A large pooled series from the breast cancer association consortium. Cancer Res 2007; 67: 9584-9590.

25. Tan D, Marchio C, Jones R, Savage K, Smith I, Dowsett $M$ and Reis-Filho J. Triple negative breast cancer: molecular profiling and prognostic impact in adjuvant anthracycline-treated patients. Breast Cancer Res Treat 2007; 10.1007/s10549-007-9756-8.

26. Wittmann BM, Sherk A and McDonnell DP. Definition of functionally important mechanistic differences among selective estrogen receptor down-regulators. Cancer Res 2007; 67: 9549-9560.

27. Wolf I, Bose S, Desmond JC, Lin BT, Williamson EA, Karlan BY and Koeffler HP. Unmasking of epigenetically silenced genes reveals DNA promoter methylation and reduced expression of PTCH in breast cancer. Breast Cancer Res Treat 2007; 105: 139-155.

28. Wood LD, Parsons DW, Jones S, Lin J, Sjoeblom T, Leary RJ, Shen D, Boca SM, Barber T, Ptak J, Silliman N, Szabo S, Dezso Z, Ustyanksky V, Nikolskaya T, Nikolsky Y, Karchin R, Wilson PA, Kaminker JS, Zhang Z, Croshaw R, Willis J, Dawson D, Shipitsin M, Willson JKV, Sukumar S, Polyak K, Park BH, Pethiyagoda CL, Pant PVK, Ballinger DG, Sparks AB, Hartigan J, Smith DR, Suh E, Papadopoulos N, Buckhaults P, Markowitz SD, Parmigiani G, Kinzler KW, Velculescu VE and Vogelstein B. The Genomic Landscapes of Human Breast and Colorectal Cancers. Science 2007; 318: 1108-1113.

29. Zheng Y, Zhou H, Modzelewski JRK, Kalak R, Blair JM, Seibel MJ and Dunstan CR. Accelerated bone resorption, due to dietary calcium deficiency, promotes breast cancer tumor growth in bone. Cancer Res 2007; 67: 9542-9548.

30. Zhou JB, Wulfkuhle J, Zhang H, Gu PH, Yang $Y Q$, Deng JH, Margolick JB, Liotta LA, Petricoin $E$ and Zhang Y. Activation of the PTEN/mTOR/ STAT3 pathway in breast cancer stem-like cells is required for viability and maintenance. Proc Natl Acad Sci USA 2007; 104: 16158-16163.

Prepared by

$R$ Sutherland

Cancer Research Program

Garvan Institute of Medical Research Darlinghurst, NSW, Australia 